\title{
HSD11B1 wt Allele
}

National Cancer Institute

\section{Source}

National Cancer Institute. HSD11B1 wt Allele. NCI Thesaurus. Code C113166.

Human HSD11B1 wild-type allele is located within 1q32-q41 and is approximately $49 \mathrm{~kb}$ in length. This allele, which encodes corticosteroid 11-beta-dehydrogenase isozyme 1 protein, plays a role in the metabolism of cortisol. Mutation of the gene is associated with cortisone reductase deficiency. 